\title{
Diversity pattern and juvenile fish assemblage in the nearshore habitats of the Sumbawa Island, Indonesia
}

\author{
Didit Abdillah ${ }^{1}$, Charles P.H. Simanjuntak ${ }^{1,2,{ }^{*}}$, Muhammmad.F. Rahardjo ${ }^{1,2}$, Djumanto $^{3}$, \\ Neri Kautsari ${ }^{4}$, Aan Saputra ${ }^{4}$ \\ ${ }^{1}$ Study Program of Aquatic Resources Management, Graduate School of Bogor Agricultural \\ University, Bogor, Indonesia \\ ${ }^{2}$ Department of Aquatic Resources Management, Faculty of Fisheries and Marine Sciences, Bogor \\ Agricultural University, Bogor, Indonesia \\ ${ }^{3}$ Department of Fisheries, Faculty of Agriculture, Gadjah Mada University, Yogyakarta, Indonesia \\ ${ }^{4}$ Department of Aquatic Resources Management, Samawa University, Sumbawa, Indonesia
}

\begin{abstract}
The coastal ecosystem plays a vital role as essential habitat for juvenile and small marine fishes. This study aimed to analyze juvenile and small-sized fish assemblage in the nearshore habitats of Sumbawa Island. Sampling was carried out in the morning at low tide when new and full moon from November 2020 to January 2021. Five sampling sites were selected based on habitats their adjacency to the river mouth. During the study period, 6349 individuals belonging to 74 species and 37 families were recorded. The number of Ambassis vachellii was the most significant, followed by Hypoatherina temminckii, and Eubleekeria splendens. The highest fish biomass was occupied by E. splendens, followed by Plotosus lineatus, and Planiliza macrolepis. Physico-chemical parameters were not varied between sampling sites, except salinity. Estuaries with vegetated areas have a higher species richness, diversity, and evenness index than the unvegetated area. Juvenile and small-sized fishes varied between sites but not varied between moon phases. Research findings confirm that the nearshore habitat of Sumbawa Island has a significant capacity to support the early life stage of many marine fish species.
\end{abstract}

\section{Introduction}

The coastal ecosystem plays an important role as essential habitat for juvenile and smallsized marine fishes. River mouths are part of an estuary ecosystem that is a transitional area for fish that migrate with various destinations from sea to the river or vice versa, and species that only use estuary [1]. The estuary has very high fish biodiversity due to nutrient input, which generally comes from river flows $[2,3]$.

River estuary ecosystems are significant for the survival of fish communities, especially juvenile fish. Fish takes benefit from the high availability of food in the form of

\footnotetext{
*Corresponding author : charles_phs@apps.ipb.ac.id
} 
phytoplankton, zooplankton, insects, and other prey in estuaries [4, 5]. Fish use estuary areas to find food and use space related to their protection and life cycle $[6,7]$.

Research conducted in estuarine ecosystems has provided information on the use of estuarine ecosystems by fish as foraging, protection, mating, spawning, nursery, and migration $[6,7,8,9]$. Various fish species have also been grouped according to their use and life cycle in estuary ecosystems $[1,10]$. Human activities are currently increasing, thus affecting the aquatic ecosystem. Current research has been carried out on Spatio-temporal distribution, relationships between habitats, environmental influences and threats, and conservation of fish in estuary ecosystems $[11,12,13]$.

The change in environmental factors mostly worsens as there are also increasing human activities in the estuary and surrounding ecosystem. Water pollution from agricultural runoff, exploitation of natural resources, industry, cities, and waste disposal negatively impact freshwater or marine fishes $[14,15]$. The low ability to manage the environment can pollute the aquatic ecosystem as the pollution in the waters spreads quickly. The ability of each species of fish is different in terms of adapting to changing environmental factors. A fish species that are not able to adapt to environmental changes can be lost from the waters. The existence of juvenile fish in the ecosystem continues to be threatened over time.

This study aimed to analyze juvenile and small-sized fish assemblage in the nearshore habitats of Sumbawa Island. The study was conducted to determine the fish that live in marine waters and fish that utilize the estuary area, both from marine and freshwater fishes.

\section{Methods}

\subsection{Study site}

The study site was located in five different sites, namely in the sandy beach, area of seagrass, and three areas of river mouth with mangrove of Sumbawa Island, West Nusa Tenggara, Indonesia (Fig. 1). The research was conducted for three months, from November 2020 to January 2021, representing the transition season, early rainy season, and the peak of the rainy season. A sampling of fish and environmental parameters was carried out in the morning when low tide and phase of the new moon and full moon.

\subsection{Data collection}

\subsubsection{Juvenile and small-sized fish}

Juvenile and small-sized fish samples were collected using a seine net with a dimension of $10 \mathrm{~m} \times 1.2 \mathrm{~m}, 4 \mathrm{~mm}$ of mesh size, and $1 \mathrm{~mm}$ mesh size of cod-end. Two persons actively operate the Seine net. The net was operated in a shallow coastal area by pulling it to the shore. The catches were sorted directly in the field and preserved using formalin 5\%. Fish was sorted based on the catch site. Preserved fish samples moved into ethanol $70 \%$ for species identification. Fishes were identified to the lowest taxon according to reference books [16], [17], [18], [19]. 


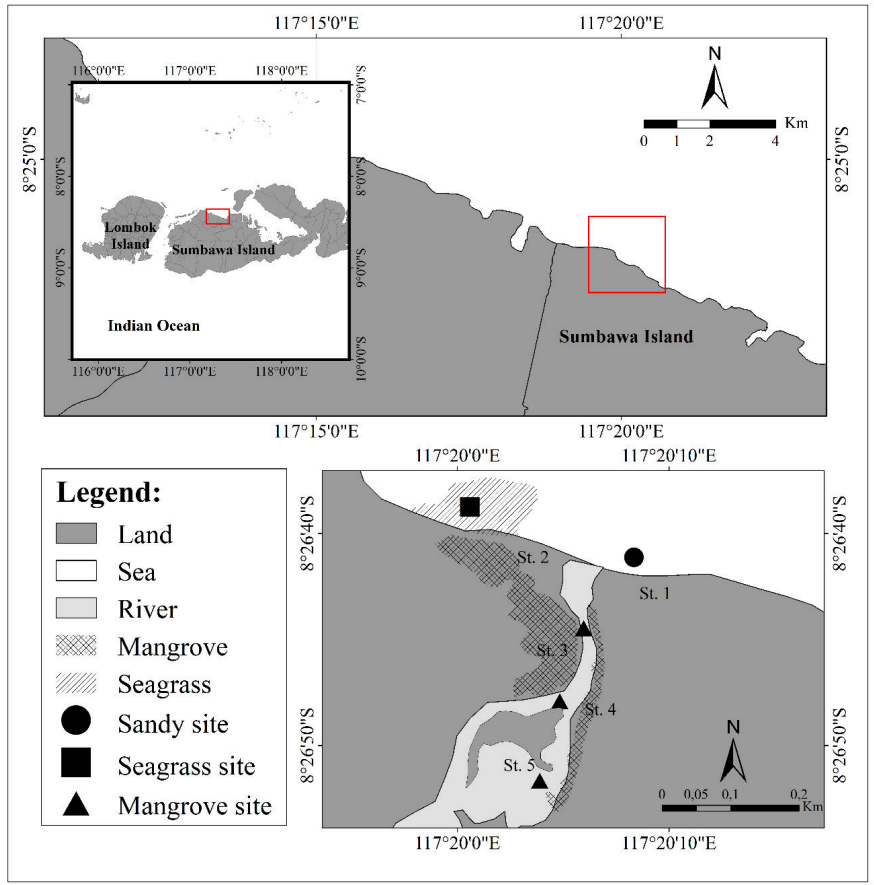

Fig. 1. Sampling locations in the nearshore habitat of Sumbawa Island.

\subsubsection{Physical and chemical parameters}

Several physicochemical parameters were measured in situ before fish samplings, such as waters depth, transparency, total dissolved solids, temperature, salinity, $\mathrm{pH}$, and dissolved oxygen to determine the condition of the waters.

\subsection{Data analysis}

\subsubsection{Fish composition}

All fish samples were grouped according to their life stages, namely juveniles and adults. The grouping is based on the ratio of the total length (TL) to the length at first maturity (LM) [20]. Data on the length at the first maturity of each species were sourced from Fishbase. If there is no data on the length at the first maturity of a fish species, it was assumed that onethird of the maximum length is the length at first maturity [21]. The fish were categorized as juveniles if their total length was less than a length at first maturity $(\mathrm{TL}<\mathrm{LM})$, while the adult stage if the total length was more than the length at first maturity (TL $>$ LM).

\subsubsection{Community structure}

Analysis on community structure was analyzed using four attributes which are ShannonWiener diversity index (H'), species richness index (D), evenness index (E), and dominance index (C) [22]. The four attributes were determined by utilizing the formula (1), (2), (3), and (4): 


$$
\begin{aligned}
& H^{\prime}=\Sigma p_{i} \ln p_{i} \\
& D=S-1 / \ln N \\
& E=H^{\prime} / H^{\prime}{ }_{\text {maks }} \\
& C=\Sigma\left(n_{i} / N\right)^{2}
\end{aligned}
$$

where $p_{i}=$ the relative abundance of each species at each sampling site, $\mathrm{H}_{\text {'maks }}^{\prime}=\ln \mathrm{S}, \mathrm{ni}=$ number of individual fish, $\mathrm{N}=$ the total number of individual fish, $\mathrm{S}=$ number of species.

\subsubsection{CPUE (Catch per Unit Effort)}

CPUE calculation is based on the number of fish from one or various species caught per unit of area (number of fish per area of sweeping). The result from the CPUE calculation used as measurement represents fish relative richness in the research site during sampling. Each species was calculated its CPUE value in each sampling site using the formula [CPUE $=\mathrm{C} / \mathrm{f}]$, CPUE: Catch per Unit Effort $\left(\mathrm{g} / 100 \mathrm{~m}^{2}\right), \mathrm{C}$ : Catch $(\mathrm{g})$, f: Area of sweep area $\left(\mathrm{m}^{2}\right)$.

\subsubsection{One-Way ANOVA and Two-Way ANOSIM}

One-way analysis of variance (ANOVA) was used to test for significant differences in environmental variables (depth, transparency, total dissolved solids, temperature, salinity, $\mathrm{pH}$, and dissolved oxygen) between different locations. While two-way analysis of similarity (ANOSIM) was used to test for site and moon condition effects for fish assemblages.

\section{Results}

\subsection{Fish diversity}

The fish caught during the study period was 74 species belonging to 37 families and 13 orders (Appendix 1). The most numerous fish species belong to the order Perciformes (41 species and 16 families). In contrast, order Atheriniformes, Batrachoidiformes, Beloniformes, Clupeiformes, Mugiliformes, Pleuronectiformes, Syngnathiformes, and Tetraodontiformes was only one to three families and one to six species (Fig. 2). The most numerous fish family caught during research was Gobiidae, represented by nine fish species, then followed by Carangidae ( 5 species), Syngnathidae, Tetraodontidae, and Zenarchopteridae (every four species) (Fig. 3). Other families that were found only constituted by one to three species (Fig. 2). 


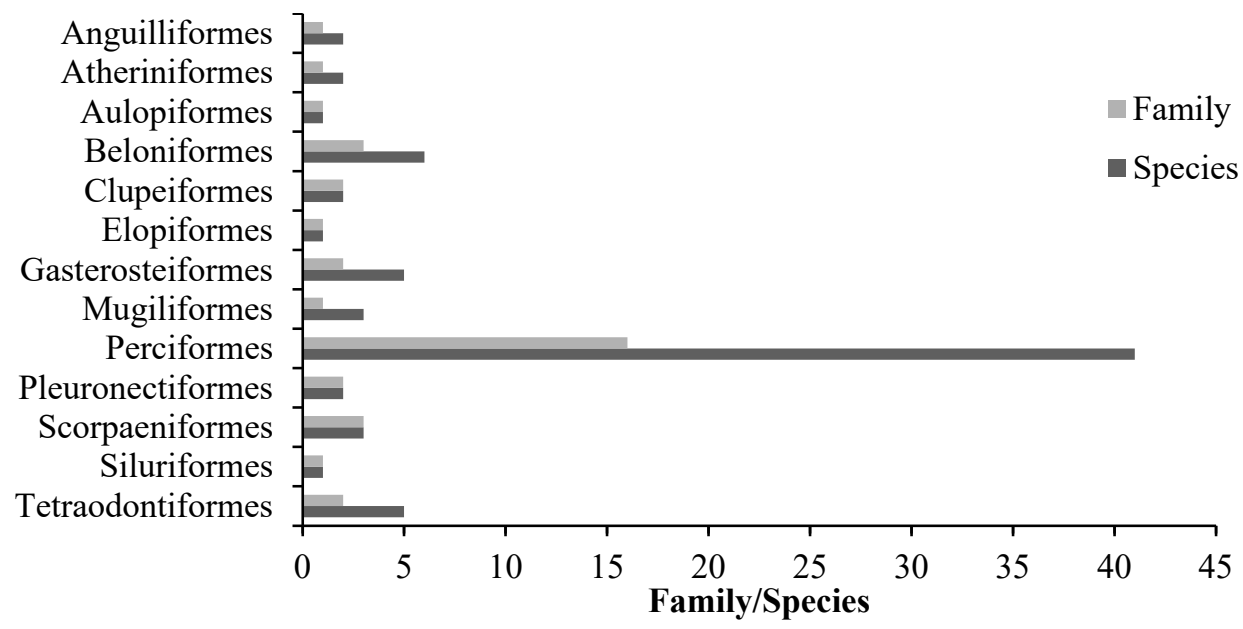

Fig. 2. The number of families and species for each fish order caught in the nearshore habitat of Sumbawa Island.

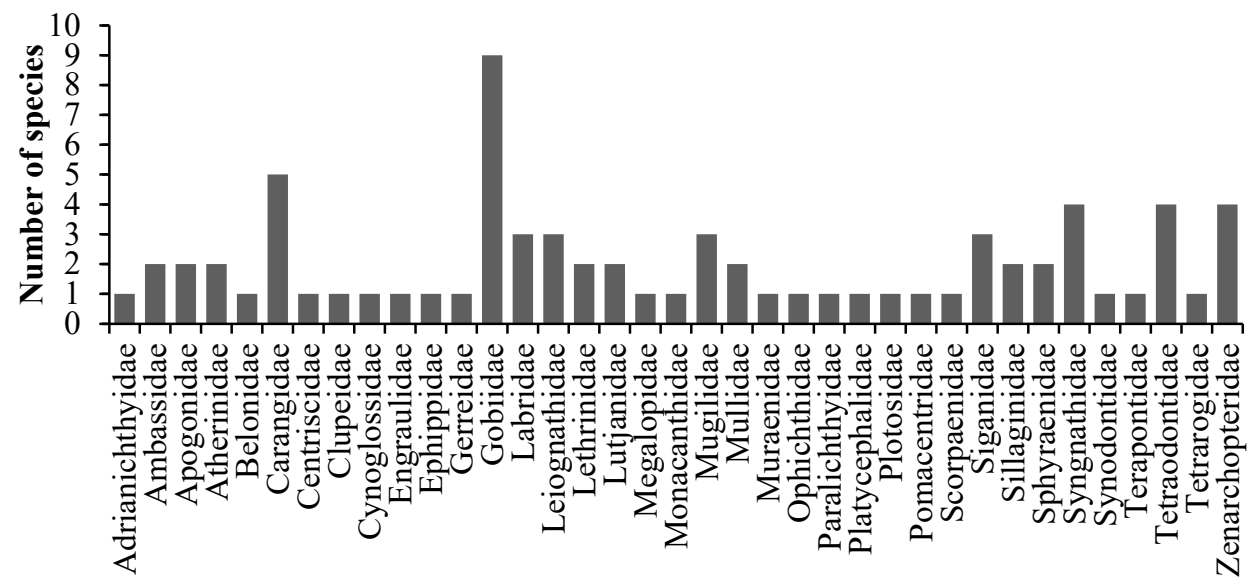

Fig. 3. Number species for each fish family caught in the nearshore habitat of Sumbawa Island.

\subsection{Fish assemblage structure}

Every fish needs an essential habitat to grow and develop. The juvenile dominated habitat utilization by fish in the study area. The abundance of juveniles in all sites was 6,067 individuals (94\%) of the 6,439 fish samples (Fig. 4). The predominant fish species based on the number of individuals and biomass was different (Fig.5). Ambassis vachellii was dominant based on the number of individuals (3242 individuals), followed by Hypoatherina temminckii and Eubleekeria splendens. The highest fish biomass was occupied by Eubleekeria splendens (1076.35 g), followed by Plotosus lineatus and Planiliza macrolepis.

The catch per unit effort (CPUE) represents the abundance of each species. Total CPUE in the nearshore habitat of Sumbawa Island was $89.43 \mathrm{Ind} . / 100 \mathrm{~m}^{2}$. The results showed that the CPUE of each fish species was varied (Appendix 1). The highest CPUE was A. vachellii (45.02 Ind./ $100 \mathrm{~m}^{2}$ ), followed by H. temminckii (8.10 Ind./ $100 \mathrm{~m}^{2}$ ), E. splendens (7.86 Ind./ $\left.100 \mathrm{~m}^{2}\right)$, P. lineatus (7.85 Ind./100 $\mathrm{m}^{2}$ ), and Stolephorus commersonnii (5.96 Ind./ $100 \mathrm{~m}^{2}$ ).

Index of the community structure of fish shows the fluctuated value (Fig. 6). Station 4 (mangrove site) has the highest average of diversity and evenness index. Station 2 (seagrass 
site) has the highest average species richness. Meanwhile, Station 1 (sandy beach) has the lowest fish diversity, evenness, and species richness.

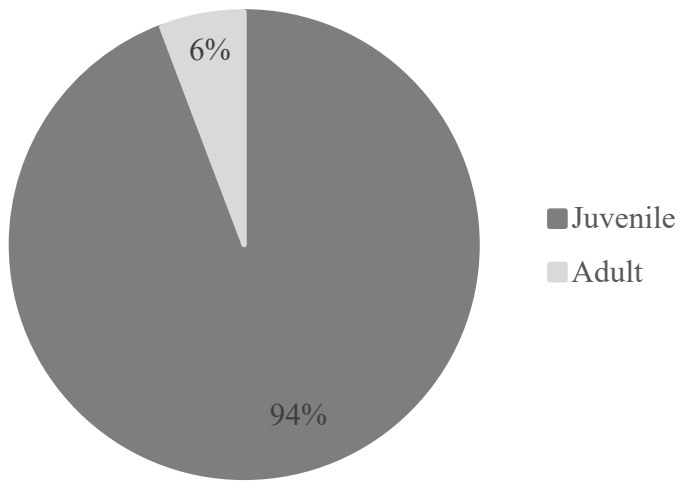

Fig. 4. Distribution of the number of a fish family caught in the nearshore habitat of Sumbawa Island.

a.

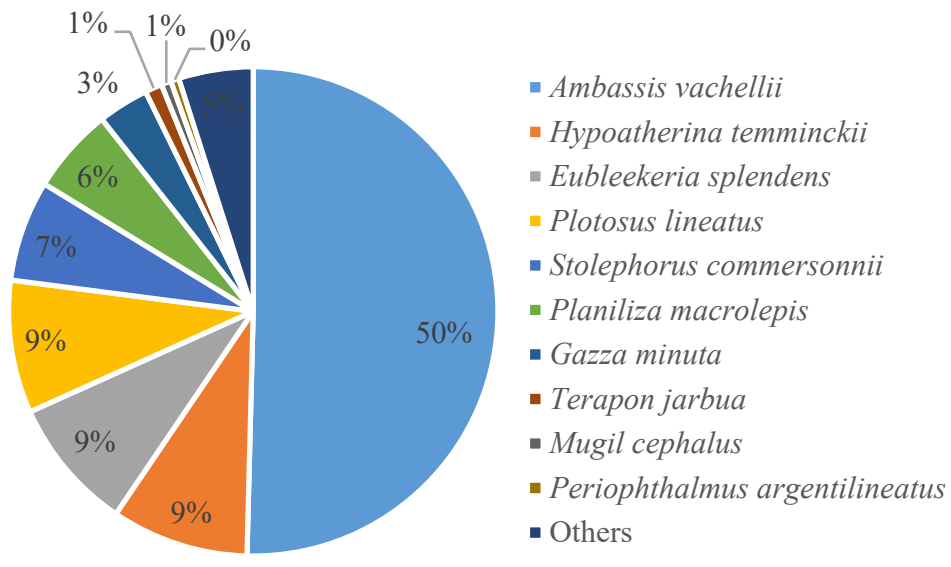

b.

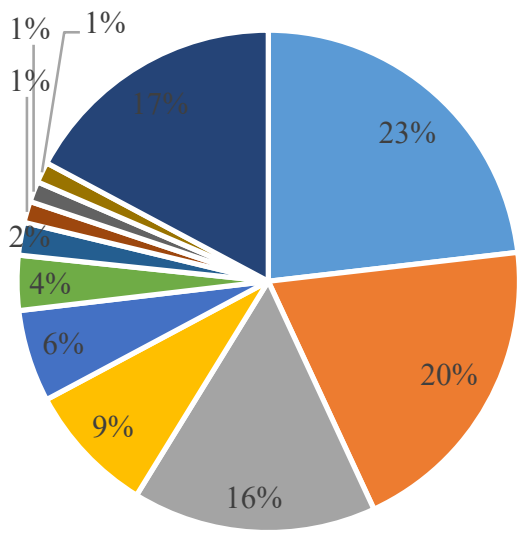

- Eubleekeria splendens

- Plotosus lineatus

- Planiliza macrolepis

- Ambassis vachellii

- Gazza minuta

- Arothron reticularis

- Crenimugil seheli

- Zenarchopterus buffonis

- Ulua mentalis

- Alectis alexandrina

- Others

Fig. 5. Species with the highest number of individuals (a) and biomass (b) in the nearshore habitat of Sumbawa Island. 

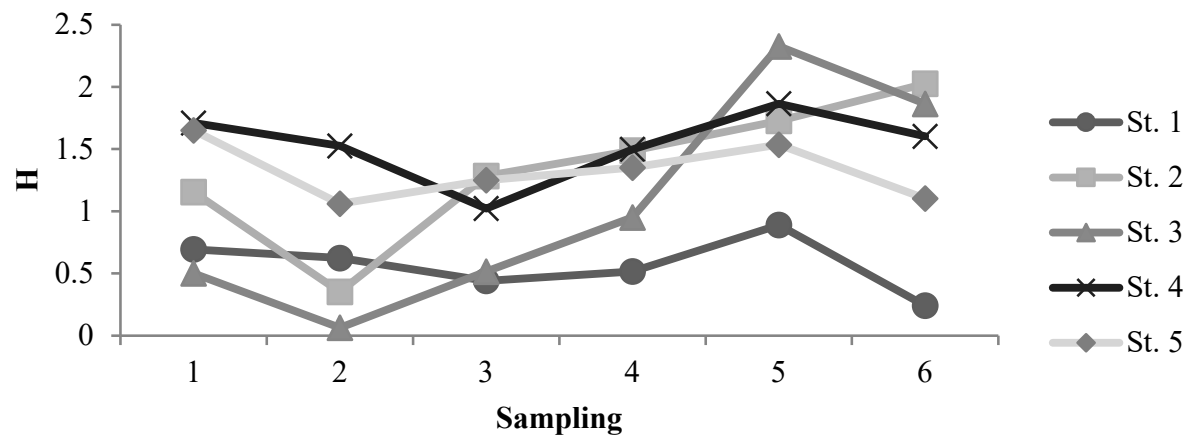

- St. 2

$\longrightarrow$ St. 3

$\because$ St. 4

St. 5

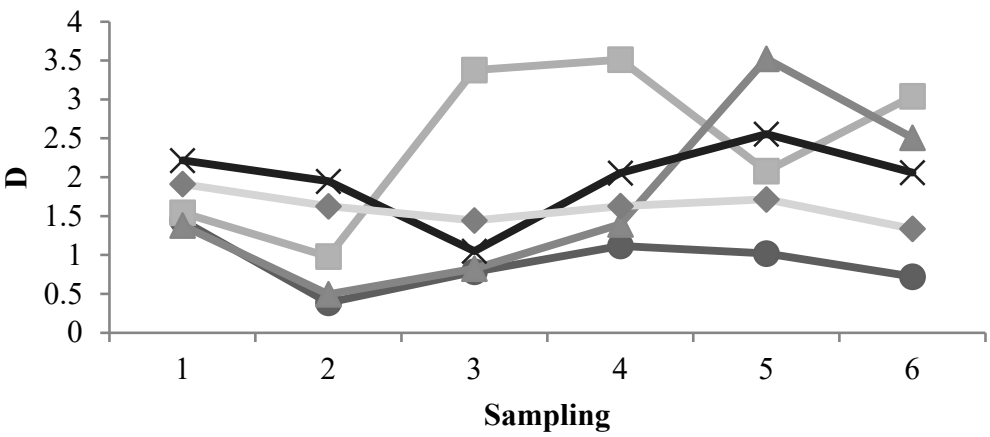

$\longrightarrow$ St. 1

- St. 2

- St. 3

$\because$ St. 4

$\leftrightarrow$ St. 5

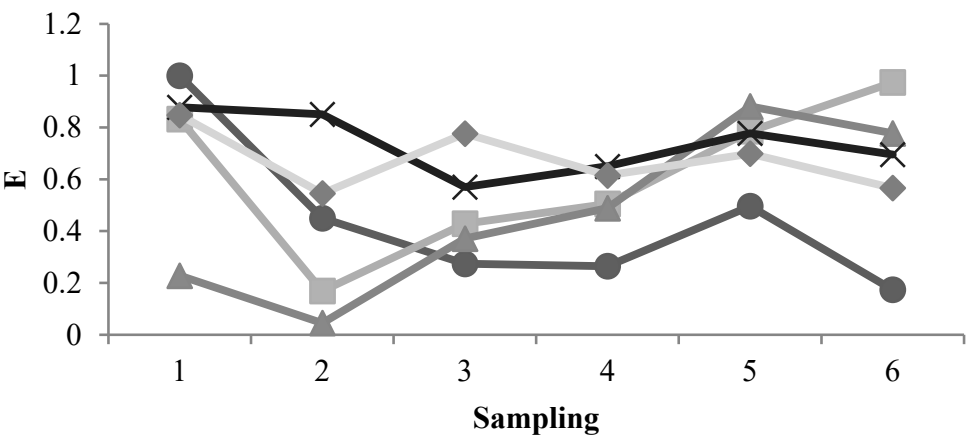

$\longrightarrow$ St. 1

- St. 2

$\longrightarrow$ St. 3

$\because$ St. 4

St. 5

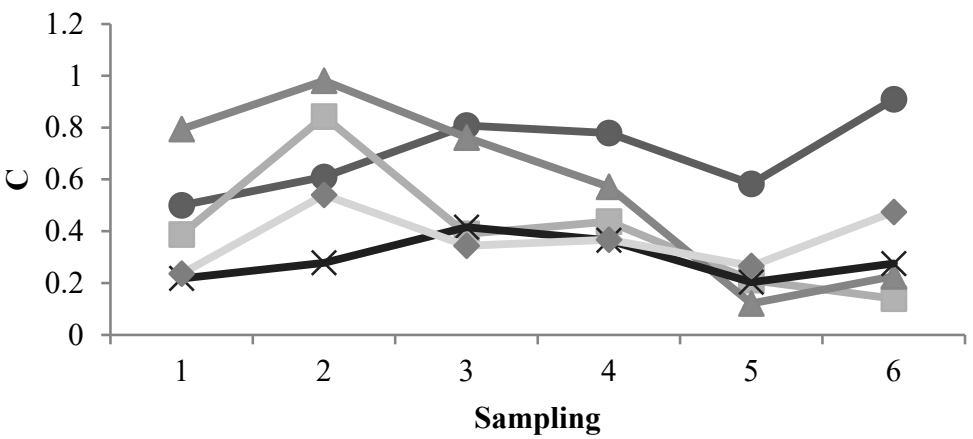

$\longrightarrow$ St. 1

- St. 2

$\longrightarrow$ St. 3

$\longrightarrow$ St. 4

St. 5

Fig. 6. Diversity index of fish assemblage in the nearshore habitat of Sumbawa Island. 


\subsection{Environmental factors}

The environmental parameters of each site are presented in Table 2. Station 3 has the highest depth average value because it locates in the lowest river mouth. The highest average values of transparency, temperature, and dissolved oxygen were recorded at Station 1. The highest average salinity was documented at Station 2 and the lowest at Station 5. All environmental parameters were not varied between sites, except for salinity.

\subsection{Correlation of environmental factors and fish composition}

ANOSIM results show that there was a significant difference between fish assemblages and sites (Table 3). The composition of fish can be affected by the different salinity at each station. Pairwise testing of fish assemblages at each station showed that the sandy beach station and the seagrass station were significantly different from all stations leading to the upstream part of the river (Stations 3, 4, and 5). The seagrass site and the sandy site did not show a significant difference.

Table 2. Summary of one-way ANOVA for environmental factors in the nearshore habitat of Sumbawa Island.

\begin{tabular}{cccccccc}
\hline Sites & $\begin{array}{c}\text { Depth } \\
(\mathrm{cm})\end{array}$ & $\begin{array}{c}\text { Trans. } \\
(\mathrm{cm})\end{array}$ & $\begin{array}{c}\text { TDS } \\
(\%)\end{array}$ & $\begin{array}{c}\text { Temp. } \\
\left({ }^{\circ} \mathrm{C}\right)\end{array}$ & $\begin{array}{c}\text { Sal. } \\
(\%)\end{array}$ & pH & $\begin{array}{c}\text { DO } \\
(\mathrm{mg} / \mathrm{L})\end{array}$ \\
\hline St. 1 & $61.1 \pm 18.4$ & $47.7 \pm 22.7$ & $771.5 \pm 478.8$ & $30.5 \pm 2.6$ & $27.3 \pm 5.2$ & $7.3 \pm 0.3$ & $9.7 \pm 1.6$ \\
St. 2 & $55.1 \pm 13.1$ & $35.6 \pm 10.8$ & $740.1 \pm 284.3$ & $29 \pm 1.2$ & $35.1 \pm 0.4$ & $7.5 \pm 0.4$ & $8.9 \pm 2.0$ \\
St. 3 & $72.1 \pm 18.4$ & $37.0 \pm 17.2$ & $699 \pm 426.2$ & $29 \pm 3.0$ & $10.6 \pm 13.4$ & $7.3 \pm 0.3$ & $7.3 \pm 2.1$ \\
St. 4 & $50.8 \pm 13.9$ & $31.3 \pm 10.9$ & $687 \pm 353.2$ & $28.1 \pm 3.0$ & $10 \pm 12.8$ & $7.3 \pm 0.3$ & $9.3 \pm 1.3$ \\
St. 5 & $42.6 \pm 19.6$ & $30.3 \pm 11.5$ & $700.8 \pm 409.6$ & $28 \pm 3.2$ & $9.6 \pm 12.6$ & $7.3 \pm 0.2$ & $8 \pm 2$ \\
F & 2.580 & 1.213 & 0.047 & 0.773 & 7.955 & 0.225 & 1.722 \\
$P$ & 0.062 & 0.330 & 0.995 & 0.553 & $0.00^{*}$ & 0.922 & 0.177 \\
\hline
\end{tabular}

$*$ : p-value $<0.05$.

Table 3. Summary of one-way ANOVA for environmental factors in the nearshore habitat of Sumbawa Island.

\begin{tabular}{lcc}
\hline & Global test & \\
\hline Spatio-temporal & $R$ & $P$ \\
\hline Moon condition & -0.0925 & 0.8529 \\
Sites & 0.2507 & $0.0018^{*}$ \\
\hline & Pairwise test & $P$ \\
\hline Pairs of site & $R$ & 0.3434 \\
\hline St. 1 vs St. 2 & 0.0305 & $0.0523^{* *}$ \\
St. 1 vs St. 3 & 0.1630 & $0.0083^{*}$ \\
St. 1 vs St. 4 & 0.4139 & $0.0048^{*}$ \\
St. 1 vs St. 5 & 0.4167 & $0.0441^{*}$ \\
St. 2 vs St. 3 & 0.2343 & $0.0024^{*}$ \\
St. 2 vs St. 4 & 0.6037 & $0.0026^{*}$ \\
St. 2 vs St. 5 & 0.5963 & $0.0499^{*}$ \\
St. 3 vs St. 4 & 0.1509 & $0.0054^{*}$ \\
St. 3 vs St. 5 & 0.3361 & 0.8597 \\
St. 4 vs St. 5 & -0.0833 & $P$ \\
\hline Pairs of moon condition & $R$ & 0.7531 \\
\hline New moon vs Full moon & -0.0258 &
\end{tabular}

$*$ : p-value $<0.05 ; * *$ : p-value $<0.1$. 


\section{Discussion}

The diversity of fish caught during research is relatively high. However, it is still considered low compared with the number of species found in the Estuary of Musi River (32 species) [23] and Poigar River Mouth (40 species) [24]. It is also different from the number of species found in other areas, which are higher in the estuary of Segara Anakan (87 species) [25] and the Estuary of Mayangan (105 species) [8]. The higher fish diversity in the nearshore habitat of Sumbawa Island is influenced by the surrounding three types of habitats and sampling, including the transitional season, the beginning of the rainy season, and the peak of the rainy season. The difference in the number of species is the consequence of various essential habitats that affect the high diversity of fish [26]. Besides, the different numbers of fish can also be caused by their habitat [27]. According to [28], the adjacent ecosystem can also affect the amount of fish diversity.

In this research, Perciformes play a significant role in nearshore habitats. Research from [29] in Cimanuk River Mouth found that the number of families from Perciformes is higher than other families. Similar research from [30] in Bintuni Bay, West Papua, found that Perciformes are higher than any other orders. Perciformes amount to more than a third of all fishes (160 families and over 10000 species) [31]. This particular family of fish from this order is distributed almost throughout the ocean [32, 33, 34, 35].

Gobiidae is the fish family with the highest number of species in the world. This family was also found to have the highest number of species in all study sites. Its ability to utilize various habitats is also a factor in the number of these species in the research location. Gobiidae is generally distributed in a wide range of coral reef habitats or areas of sandy, rubble, and muddy areas ranging from tidal pools to offshore coral reefs $[19,36]$.

Fish juveniles utilize all the habitats of sandy beaches, seagrasses, and mangroves in the estuary ecosystem. More than half of the species in estuary ecosystems are juveniles only [37]. [38] support this statement by stating that more than half (57\%) of the total fish species in the estuary ecosystem are only juveniles. The highest number of juveniles shows that the estuary ecosystem is essential habitat for fish juveniles [39]. Habitat utilization by fish juveniles indicates that the area is used as a nursery area and can also be used as a feeding or breeding route $[1,10]$. However, based on the high abundance and frequency of juveniles of each species, it is strongly suspected that juveniles of fishes utilize various habitats in the estuary of the study area as a nursery ground.

The total CPUE of all fish catches was 89.43 individuals/ $100 \mathrm{~m}^{2}$. The value was higher than in Kema, North Minahasa (15.03 individuals/ $100 \mathrm{~m}^{2}$ ) [40]. Environmental factors, population dynamics have a major influence on catches [41]. Currents, sea level, surface temperature, chlorophyll-a concentration, and total suspended solids affect CPUE [42]. The mangrove habitat, seagrass habitat, and sandy beach in the research location support the estuary ecosystem.

The high abundance of Ambassis vachellii is due to its ability to utilize different habitats in the estuary and surrounding ecosystems. This species was found in a large number in seagrass, sandy, and mangrove habitats. Previous studies showed that $A$. vachellii is widely spread from coastal estuaries to upper river areas or upstream rivers [43] and includes areas around bays where seagrass meadows are found [44]. The high abundance of $A$. vachellii in estuary locations was also found by [45]. They found that juveniles of $A$. vachellii were abundant in waters with mangrove habitats and could even be grouped as species that use mangrove as its habitat. The habitat of this species includes the bay area with brackish waters, estuaries, and tidal areas where mangroves are found [19, 38]. In addition, A. vachellii can spawn many times during its life cycle due to its long lifespan compared to other species in estuaries [46]. 
E. splendens has a greater ability to utilize various habitats. Therefore it was often found in diverse habitats. Certain species may occupy more than one type of habitat, and this is due to their excellent tolerance level to various environmental factors, habitat proximity factors, and connectivity with other habitats [10,47].

A total of 10 species that dominate based on the number of individuals $(95.09 \%)$ was more significant than the total biomass $(82.82 \%)$. The dominance that occurs based on the number of individuals was more visible than the total biomass. The dominant fish species are generally smaller compared with other fish and forms schooling in the waters. Small-sized fishes and juveniles are more dominant than large fish in utilizing estuaries in tropical waters $[25,38,48]$. This result was shown by the abundance of juveniles $A$. vachellii $(1,740$ individuals, mean $\mathrm{SL}=9 \mathrm{~mm}$ ) and $H$. temmickii (580 individuals, mean $\mathrm{SL}=15.53 \mathrm{~mm}$ ) in sandy site and seagrass site. The abundance of the juvenile $A$. vachellii is presumably because the juvenile of $A$. vachellii were just about to enter the estuary area, which is their habitat. The abundance of this species was always found in high numbers in estuaries, both in areas with sand and mud substrates [49]. Appearance at one location and abundantly indicates $H$. temminckii forms schooling in the sandy site. According to [34], H. temminckii was commonly found in coastal waters and ports.

The higher fish diversity is mostly recorded in the vegetated areas, such as seagrass and mangrove $[45,50]$. The diversity value is used as an indicator for monitoring environmental changes [51] because each fish species has a different tolerance to water quality, habitat, and other environmental parameters [52].

The seagrass site is farthest from the river mouth, so it has high salinity. The more towards the upstream of the river, salinity is lower. The salinity distribution can also be affected by water circulation, evaporation, and rainfall [53]. The fish that occupy estuary waters are estuarine residents, euryhaline marine migrants, stenohaline marine, freshwater migrants, catadromous migrants, and anadromous migrants [54]. High salinity at the seagrass and sandy sites were utilized by juveniles of marine fish belonging to the stenohaline groups. This group has a large number of species, including various types of marine fish. However, species richness is higher in high salinity coastal areas than in estuarine areas due to the influence of the high number of taxa in the marine environment compared with the estuary, the low ability for freshwater fish species to enter high salinity areas, or the low ability for marine fish species to enter low salinity areas [55].

Increasing salinity in estuaries can provide greater opportunities for marine species to utilize habitats in estuaries [56]. Increases in salinity can happen especially during the dry season, when the volume of river water is small, or at the farthest tide when the new moon and full moon. The study was conducted during the transitional and rainy seasons when the volume of river water increases, resulting in a decrease in salinity in the estuary. The decrease causes the stenohaline fish only to occupy seagrass and sandy beaches. Meanwhile, the estuary area was inhabited mostly by permanent resident fish of the estuary such as Amblygobius linki, Zenarchopterus buffonis, Periophthalmus argentilineatus, Chelonodon patoca, and Favonigobius reichei and marine euryhaline fish like Ambassis vachellii, Eubleekeria splendens, Planiliza macrolepis, Terapon jarbua, Mugil cephalus, and Stolephorus commersonnii. This group has a high diversity and large numbers due to their tolerance to various water salinities [54].

There was no significant difference in fish assemblages between Station 4 and Station 5 in the mangrove area upstream of the estuary. This similarity is strongly suspected because of the increase in salinity due to high tides that is relatively low at that two stations. Therefore, marine stenohaline species do not take advantage of this habitat, unlike the case at station 3 in the mangrove area, which is the main entrance of seawater to the estuary area. Tidal currents carry water masses along with marine fish to enter the lower reaches of the estuary. 
Marine fish utilize the increase in salinity of the waters downstream to serve as their essential habitat temporarily [56].

Each species has a different ability to adapt to environmental factors. Specific habitats will continue to be utilized by several species of fish despite changes in environmental factors. Therefore, various ecosystems' habitats can significantly affect the diversity and abundance of fish shown by the sandy site, an essential habitat for H. temminckii. This species is found abundantly on the coast and from schooling [33]. Cheilio inermis was only found in seagrass areas. This species is a stenohaline character fish and utilizes seagrass habitat in the juvenile stage [57]. Although it is not significantly different in species composition, there were 32 species found in seagrass but not in sandy beach areas. The high number of species is due to various species using seagrass areas for camouflage between the leaves and stems of the seagrass [31] to avoid predators so that the sustainability of the population is maintained. Families such as Siganidae, Atherinidae, Labridae, Nemipteridae, and various reef fish families are interested in seagrass ecosystems, especially in the juvenile phase [58, $59,60,61]$.

\section{Conclusion}

A total of 74 fish species from 37 families and 13 orders dwelled in the nearshore habitat of Sumbawa Island. The fish assemblage is dominated by fish juveniles (94\%), and they occupy various habitats such as mangroves, seagrass, and sandy beach. Estuaries with vegetated areas have a higher species richness, diversity, and evenness index than the unvegetated area. Moreover, salinity is an environmental parameter that significantly varies between sampling sites and affects the fish assemblages. The nearshore habitat of Sumbawa Island has a significant capacity to support the early stage of many marine fish species.

\section{References}

1. M. Elliott, A.K. Whitfield, I.C. Potter, S.J.M. Blaber, D.P. Cyrus, F.G. Nordlie, T.D. Harrison. Fish and Fish. 8, 3 (2007)

2. P.J. Statham, Sci. Total Environ. 434, 213-227 (2012)

3. D.S. Pramanik, Int. J. Fish. Aquat. Stud. 7, 1 (2019)

4. H.W. Paerl, Ecol. Eng. 26, 40-54 (2006)

5. M.S.N. Chowdhury, M.S. Hossain, S.R.Chowdhury, N.G. Das, Bangladesh J. Fish. Res. 1, 1 (2009)

6. E. Wolanski, M. Elliot, Estuarine ecohydrology (second edition) (Elsevier, Amsterdam, 2016)

7. M. Sharifinia, M. Daliri, E. Kamrani, Coasts and estuaries: the future (Elsevier, Amsterdam, 2019)

8. A. Zahid, C.P.H. Simanjuntak, M.F. Rahardjo, Sulistiono, J. Iktiologi Indones. 11, 1 (2011)

9. S.J.M. Blaber, M. Barletta, J. Fish. Biol. 89, 1 (2016).

10. L. Phil, A. Cattrijsse, I. Codling, S. Mathieson, D.S. McLusky, C. Roberts, Fishes in estuaries (Blackwell Science, Iowa, 2002)

11. Q. Guo, X. Liu, X. Ao, J. Qin, X. Wu, S. Ouyang, PLoS One 13, 11 (2018)

12. J. Vieira, V. Roman-Robles, F. Rodrigues, L. Ramos, M.L. dos Santos, Front. Mar. Sci. 6, 269 (2019) 
13. J. Du, M. Xie, Y. Wang, Z. Chen, W. Liu, J. Liao, B. Chen, Acta Oceanol. Sin. 39, 43 52 (2020)

14. R. Beiras, Marine pollution, sources, fate and effects of pollutants in coastal ecosystems (Elsevier, Amsterdam, 2018)

15. D.P. Hader, A.T. Banaszak, V.E. Villafane, M.A. Narvarte, R.A. González, E.W. Helbling, Sci. Total Environ. 713, 136586 (2020)

16. FAO Species Identification Guide for Fishery Purposes. The Living Marine Resources of the Western Central Pacific (FAO, Rome, 2001)

17. G. Allen, Marine fishes of South East Asia (Western Australian Museum, Perth, 1997)

18. R.H. Kuiter, T. Tonozuka, Pictorial guide to Indonesian reef fishes (Zoonetics, Australia, 2001)

19. G.R. Allen, M.V. Erdmann, Reeffishes of the East Indies (Tropical Reef Research, Perth, 2012)

20. R. Froese, D. Pauly, FishBase, http://www.fishbase.org/ (2019)

21. I. Nagelkerken, G. van der Velde, Mar. Ecol. Prog. Ser. 245, 191-204 (2002)

22. A.E. Magurran, Measuring biological diversity (Blackwell Publishing, London, 2004)

23. M.R. Ridho, E. Patriono, J. Penelit. Sains, 19, 1 (2017)

24. N Kamurahan, N.E. Bataragoa, A.V. Lohoo, J. Perikanan dan Kelaut. Trop. 11, 1 (2020)

25. A Nurfiarini, M.M. Kamal, L. Adrianto, SB Susilo, BAWAL, 7, 1 (2015)

26. F.K. Muzaki, D. Saptarini, A.S. Ibadah, Biodiversitas, 20, 6 (2019)

27. A.J. Hamilton, J. Environ. Manage. 75, 85-92 (2005)

28. M. Adrim, J. Oseana 31, 4 (2006)

29. P.A.R.P. Tampubolon, Y. Ernawati, M.F. Rahardjo, Ber. Biologi, 17, 1 (2018)

30. C.P.H. Simanjuntak, Sulistiono, M.F. Rahardjo, A. Zahid, J. Iktiologi Indones. 11, 2 (2011)

31. G.N Helfman, B.B. Collette, D.E. Facey, B.W. Bowen, The diversity of fishes: biology, evolution, and ecology (Wiley-Blackwell, West Sussex, 2009)

32. K.E. Carpenter, V.H. Niem, FAO species identification guide for fishery puposes. The living marine resources of Western Central Pacific. Volume 3. Batoid fishes, chimaeras, and bony fishes part 1 (Elopidae to Linophrynidae) (FAO, Rome, 1999)

33. K.E. Carpenter, V.H. Niem, FAO species identification guide for fishery puposes. The living marine resources of Western Central Pacific. Volume 4. Bony fishes part 2 (Mugilidae to Carangidae), (FAO, Rome, 1999)

34. K.E. Carpenter, V.H. Niem, FAO species identification guide for fishery puposes. The living marine resources of Western Central Pacific. Volume 5. Bony fishes part 3 (Menidae to Pomacentridae), (FAO, Rome, 2001)

35. K.E. Carpenter, V.H. Niem, FAO species identification guide for fishery puposes. The living marine resources of Western Central Pacific. Volume 6. Bony fishes part 4 (Labridae to Latimeriidae). (FAO, Rome, 2001)

36. J.S. Nelson, Fishes of the world (John Wiley \& Sons Inc, New Jersey, 2006)

37. P. Tongnunui, K. Ikejima, T, Yamane, M. Horinouchi, T. Medej, M. Sano, H. Kurokura, T. Taniuchi, Fish Sci. 68, 10-17 (2002)

38. K. Ikejima, P. Tongnunui, T. Medej, T. Taniuchi, Estuar. Coast. Shelf. Sci. 56, 447-457 (2003) 
39. V. Mendonca, A.A.V. Flores, A.C.F. Silva, C. Vinagre, Estuar. Coast. Shelf. Sci. 225, 106255 (2019)

40. J. Du, Y. Wang, T. Peristiwady, J. Liao, P.C. Makatipu, R. Huwae, P. Ju, K.H. Loh, B. Chen, Acta. Oceanol. Sin. 37, 12 (2018)

41. M.N. Maunder, J.R. Sibert, A. Fonteneau, J. Hampton, P. Kleiber, S.J. Harley, ICES Mar. Sci. Symp. 63, 8 (2006)

42. A.A. Rivai, V.P. Siregar, S.B. Agus, H. Yasuma, IOP Conf. Ser.: Earth Environ. Sci. 139, 012014 (2018)

43. S. Irhami, A. Fithri, A.S. Batubara, Z.A. Muchlisin, IOP Conf. Ser.: Earth Environ. Sci., 216, 012023 (2018)

44. W. Phinrub, B. Montien-Art, J. Promya, A. Suvarnaraksha, Open J. Ecol. 5, 563-573 (2015)

45. S. Sichum, P. Tantichodok, Raffles Bull. Zool. 61, 2 (2013)

46. Q.M. Dinh, Y.T.N. Nguyen, T.H. Dang, N.S. Tran, T.T.H. Lam, Egypt. J. Aquat. Biol. 24, 2 (2020)

47. C.M. Huijbers, M.G.G Grol, I. Nagelkerken, Rev. Biol. Trop. 56, 161-169 (2008)

48. E. Prianto, N.K. Suryati, Jurnal Penelitian Perikanan Indonesia, 16, 1 (2010)

49. R. Johnston, M. Sheaves, B. Molony, J. Fish Biol. 71, 3 (2007)

50. M. Horinouchi, Laguna 12, 69-72 (2005)

51. A.A.H. Siddig, A.M. Ellison, A. Ochs, C. Villar-Leeman, M.K. Lau, Ecol. Indic. 60, 223-230 (2016)

52. J.R. Karr, Fisheries 6, 6 (1981)

53. A. Nontji, Archipelago sea (Penerbit Djambatan, Jakarta, 2002)

54. A.K. Whitfield, J. Fish. Biol. 86, 4 (2015)

55. A.K. Whitfield, M. Elliott, A. Basset, S.J.M. Blaber, R.J. West, Estuarine, Estuar. Coast. Shelf. Sci. 97, 78-90 (2012)

56. M.G. Castro, J.M.D. Astarloa, M.B. Cousseau, D.E. Figueroa, S.M. Delpiani, D.O. Bruno, J.M. Guzzoni, G.E. Blasina, M.Y.D. Antoni, J. Mar. Biolog. 89, 3 (2009)

57. R.K.F. Unsworth, J.J. Bell, D.J. Smith, J. Mar. Biolog. 87, 1287-1296 (2007)

58. T.E. Kuriandewa, W. Kiswara, M. Hutomo, S. Soemodihardjo, World atlas of seagrasses (University of California Press, Berkeley, 2003)

59. R.K.F. Unsworth, P.S.D. Leon, S.L. Garrard, J. Jompa, D.J. Smith, J.J. Bell, Mar. Ecol. Prog. Ser. 353, 213-224 (2008)

60. R.A. Rappe, J. Ilmu Teknol. Kelaut. Trop. 2 (2010)

61. T. Triandiza, ISOI, 1-14 (2017) 


\section{Appendix}

Appendix 1. Number of individuals (N), total of weight (W), CPUE (Ind./100 $\mathrm{m}^{2}$ ), standard length (SL), and life stages (LS: J, juveniles; A, adults) of fish collected by sampling sites in the nearshore habitat of Sumbawa Island

\begin{tabular}{|c|c|c|c|c|c|c|c|c|c|c|c|c|}
\hline \multirow{2}{*}{ No. } & \multirow{2}{*}{ Order/ Family } & \multirow{2}{*}{ Species } & \multicolumn{5}{|c|}{ Sampling sites } & \multirow{2}{*}{$\mathrm{N}$} & \multirow{2}{*}{$\mathrm{W}(\mathrm{g})$} & \multirow{2}{*}{ CPUE } & \multirow{2}{*}{$\mathrm{SL}(\mathrm{cm})$} & \multirow{2}{*}{ LS } \\
\hline & & & St. 1 & St. 2 & St. 3 & St. 4 & St. 5 & & & & & \\
\hline & \multicolumn{12}{|c|}{ ANGUILLIFORMES } \\
\hline 1. & Muraenidae & Echidna rhodochilus & 0 & 0 & 1 & 0 & 0 & 1 & 13.3 & 0.01 & $172-172$ & A \\
\hline 2. & Ophichthidae & Ophichthus altipennis & 0 & 2 & 0 & 0 & 0 & 2 & 26.9 & 0.03 & $235-338$ & $\mathrm{~J}$ \\
\hline & \multicolumn{12}{|c|}{ ATHERINIFORMES } \\
\hline 3. & Atherinidae & Doboatherina duodecimalis & 0 & 3 & 0 & 0 & 0 & 3 & 0.13 & 0.04 & $19-20$ & $\mathrm{~J}$ \\
\hline 4. & & Hypoatherina temminckii & 582 & 1 & 0 & 0 & 0 & 583 & 11.66 & 8.10 & $4-41$ & $\mathrm{~J}, \mathrm{~A}$ \\
\hline & \multicolumn{12}{|c|}{ AULOPIFORMES } \\
\hline 5. & $\begin{array}{l}\text { Synodontidae } \\
\text { BELONIFORMES }\end{array}$ & Saurida nebulosa & 0 & 1 & 0 & 0 & 0 & 1 & 53.52 & 0.01 & $156-156$ & A \\
\hline 6. & Adrianichthyidae & Oryzias javanicus & 0 & 0 & 0 & 0 & 1 & 1 & 0.14 & 0.01 & $20-20$ & A \\
\hline 7. & Belonidae & Platybelone argalus platyura & 0 & 0 & 0 & 3 & 1 & 4 & 3.56 & 0.06 & $64-96$ & $\mathrm{~J}$ \\
\hline 8. & Zenarchopteridae & Zenarchopterus buffonis & 0 & 1 & 4 & 10 & 3 & 18 & 63.99 & 0.25 & $27-152$ & $\mathrm{~J}$ \\
\hline 9. & & Zenarchopterus dispar & 0 & 0 & 2 & 3 & 0 & 5 & 21.66 & 0.07 & $59-105$ & A \\
\hline 10. & & Zenarchopterus dunckeri & 0 & 0 & 1 & 0 & 0 & 1 & 8.2 & 0.01 & $88-88$ & $\mathrm{~A}$ \\
\hline 11. & & Zenarchopterus rasori & 0 & 0 & 2 & 0 & 5 & 7 & 12.26 & 0.10 & $45-112$ & $\mathrm{~J}, \mathrm{~A}$ \\
\hline & \multicolumn{12}{|c|}{ CLUPEIFORMES } \\
\hline 12. & Clupeidae & $\begin{array}{l}\text { Herklotsichthys } \\
\text { quadrimaculatus }\end{array}$ & 1 & 0 & 0 & 0 & 0 & 1 & 0.26 & 0.01 & $25-25$ & $\mathrm{~J}$ \\
\hline 13. & $\begin{array}{l}\text { Engraulidae } \\
\text { ELOPIFORMES }\end{array}$ & Stolephorus commersonnii & 179 & 246 & 2 & 0 & 2 & 429 & 55.77 & 5.96 & $15-66$ & $\mathrm{~J}$ \\
\hline 14. & $\begin{array}{l}\text { Megalopidae } \\
\text { GASTEROSTEIFC }\end{array}$ & $\begin{array}{l}\text { Megalops cyprinoides } \\
\text { ORMES }\end{array}$ & 1 & 9 & 0 & 0 & 0 & 10 & 0.67 & 0.14 & $18-32$ & $\mathrm{~J}$ \\
\hline 15. & Centriscidae & Aeoliscus strigatus & 0 & 1 & 0 & 0 & 0 & 1 & 0.08 & 0.01 & $36-36$ & $\mathrm{~J}$ \\
\hline 16. & Syngnathidae & Hippichthys cyanospilos & 0 & 1 & 0 & 0 & 0 & 1 & 0.8 & 0.01 & $96-96$ & A \\
\hline
\end{tabular}




\begin{tabular}{|c|c|c|c|c|c|c|c|c|c|c|c|c|}
\hline \multirow{2}{*}{ No. } & \multirow{2}{*}{ Order/ Family } & \multirow{2}{*}{ Species } & \multicolumn{5}{|c|}{ Sampling sites } & \multirow[b]{2}{*}{$\mathrm{N}$} & \multirow[b]{2}{*}{$\mathrm{W}(\mathrm{g})$} & \multirow{2}{*}{ CPUE } & \multirow[b]{2}{*}{$\mathrm{SL}(\mathrm{cm})$} & \multirow{2}{*}{ LS } \\
\hline & & & St. 1 & St. 2 & St. 3 & St. 4 & St. 5 & & & & & \\
\hline 17. & & Hippocampus kuda & 1 & 0 & 0 & 0 & 0 & 1 & 3.2 & 0.01 & $80-80$ & $\mathrm{~J}$ \\
\hline 18. & & Microphis leiaspis & 0 & 0 & 1 & 1 & 1 & 3 & 0.21 & 0.04 & $54-60$ & $\mathrm{~J}$ \\
\hline \multirow[t]{2}{*}{19.} & & Syngnathoides biaculeatus & 0 & 1 & 0 & 0 & 0 & 1 & 4.31 & 0.01 & $175-175$ & A \\
\hline & \multicolumn{12}{|c|}{ MUGILIFORMES } \\
\hline 20. & Mugilidae & Crenimugil seheli & 0 & 0 & 0 & 9 & 12 & 21 & 97.54 & 0.29 & $44-83$ & $\mathrm{~J}$ \\
\hline 21. & & Mugil cephalus & 16 & 1 & 3 & 6 & 16 & 42 & 0.97 & 0.58 & $8-12$ & $\mathrm{~J}$ \\
\hline \multirow[t]{2}{*}{22.} & & Planiliza macrolepis & 1 & 0 & 5 & 150 & 208 & 364 & 729.2 & 5.06 & $10-84$ & $\mathrm{~J}$ \\
\hline & PERCIFORMES & & & & & & & & & & & \\
\hline 23. & Ambassidae & Ambassis interrupta & 0 & 0 & 0 & 1 & 0 & 1 & 1.47 & 0.01 & $35-35$ & $\mathrm{~J}$ \\
\hline 24. & & Ambassis vachellii & 1751 & 1165 & 141 & 112 & 73 & 3242 & 391.41 & 45.03 & $7-56$ & $\mathrm{~J}, \mathrm{~A}$ \\
\hline 25. & Apogonidae & Fibramia amboinensis & 0 & 2 & 2 & 0 & 1 & 5 & 11.17 & 0.07 & $15-54$ & $\mathrm{~J}, \mathrm{~A}$ \\
\hline 26. & & Fibramia lateralis & 0 & 3 & 0 & 0 & 0 & 3 & 0.12 & 0.04 & $13-16$ & $\mathrm{~J}$ \\
\hline 27. & Carangidae & Alectis indica & 0 & 1 & 0 & 0 & 0 & 1 & 8.7 & 0.01 & $64-64$ & $\mathrm{~J}$ \\
\hline 28. & Carangidae & Alectis alexandrina & 0 & 4 & 0 & 0 & 0 & 4 & 62.15 & 0.06 & $62-91$ & $\mathrm{~J}$ \\
\hline 29. & & Caranx ignobilis & 0 & 0 & 0 & 0 & 1 & 1 & 9.85 & 0.01 & $77-77$ & $\mathrm{~J}$ \\
\hline 30. & & Selar crumenophthalmus & 0 & 0 & 0 & 3 & 0 & 3 & 0.82 & 0.04 & $24-26$ & $\mathrm{~J}$ \\
\hline 31. & & Ulua mentalis & 5 & 0 & 0 & 0 & 0 & 5 & 62.2 & 0.07 & $61-80$ & $\mathrm{~J}$ \\
\hline 32. & Ephippidae & Platax orbicularis & 0 & 3 & 0 & 0 & 1 & 4 & 22.02 & 0.06 & $14-59$ & $\mathrm{~J}$ \\
\hline 33. & Gerreidae & Gerres oyena & 0 & 0 & 0 & 3 & 2 & 5 & 3.8 & 0.07 & $13-43$ & $\mathrm{~J}$ \\
\hline 34. & Gobiidae & Amblygobius linki & 0 & 0 & 20 & 6 & 0 & 26 & 21.24 & 0.36 & $27-54$ & $\mathrm{~J}, \mathrm{~A}$ \\
\hline 35. & & Bathygobius cyclopterus & 0 & 1 & 0 & 0 & 0 & 1 & 0.21 & 0.01 & $21-21$ & A \\
\hline 36. & & Favonigobius reichei & 0 & 0 & 3 & 8 & 13 & 24 & 9.85 & 0.33 & $16-41$ & $\mathrm{~J}, \mathrm{~A}$ \\
\hline 37. & & Glossogobius bicirrhosus & 0 & 0 & 0 & 1 & 0 & 1 & 0.2 & 0.01 & $25-25$ & $\mathrm{~J}$ \\
\hline 38. & & Oligolepis acutipennis & 0 & 0 & 0 & 1 & 2 & 3 & 2.91 & 0.04 & $13-49$ & $\mathrm{~J}, \mathrm{~A}$ \\
\hline 39. & & Oxyurichthys ophthalmonema & 0 & 0 & 6 & 0 & 0 & 6 & 1.22 & 0.08 & $12-33$ & $\mathrm{~J}$ \\
\hline 40. & & Periophthalmus argentilineatus & 0 & 0 & 6 & 17 & 12 & 35 & 57.16 & 0.49 & $19-62$ & $\mathrm{~J}, \mathrm{~A}$ \\
\hline 41. & & Psammogobius biocellatus & 0 & 0 & 0 & 1 & 0 & 1 & 3.9 & 0.01 & $63-63$ & A \\
\hline 42. & & Sicyopterus lagocephalus & 0 & 1 & 2 & 2 & 0 & 5 & 0.77 & 0.07 & $14-26$ & $\mathrm{~J}$ \\
\hline 43. & Labridae & Cheilio inermis & 0 & 6 & 0 & 0 & 0 & 6 & 24.6 & 0.08 & $30-141$ & $\mathrm{~J}$ \\
\hline
\end{tabular}




\begin{tabular}{|c|c|c|c|c|c|c|c|c|c|c|c|c|}
\hline \multirow{2}{*}{ No. } & \multirow{2}{*}{ Order/ Family } & \multirow{2}{*}{ Species } & \multicolumn{5}{|c|}{ Sampling sites } & \multirow{2}{*}{$\mathrm{N}$} & \multirow{2}{*}{$\mathrm{W}(\mathrm{g})$} & \multirow{2}{*}{ CPUE } & \multirow{2}{*}{$\mathrm{SL}(\mathrm{cm})$} & \multirow{2}{*}{ LS } \\
\hline & & & St. 1 & St. 2 & St. 3 & St. 4 & St. 5 & & & & & \\
\hline 44. & & Halichoeres argus & 1 & 3 & 0 & 0 & 0 & 4 & 17.33 & 0.06 & $42-68$ & $\mathrm{~A}$ \\
\hline 45. & & Halichoeres papilionaceus & 0 & 1 & 0 & 0 & 0 & 1 & 5.99 & 0.01 & $64-64$ & $\mathrm{~A}$ \\
\hline 46. & \multirow[t]{2}{*}{ Leiognathidae } & Deveximentum interruptum & 21 & 5 & 0 & 0 & 0 & 26 & 8.51 & 0.36 & $13-28$ & $\mathrm{~J}, \mathrm{~A}$ \\
\hline 47. & & Eubleekeria splendens & 176 & 91 & 298 & 1 & 0 & 566 & 1076.35 & 7.86 & $8-68$ & $\mathrm{~J}, \mathrm{~A}$ \\
\hline 48. & Leiognathidae & Gazza minuta & 190 & 33 & 1 & 0 & 0 & 224 & 276.17 & 3.11 & $8-42$ & $\mathrm{~J}$ \\
\hline 49. & \multirow[t]{2}{*}{ Lethrinidae } & Lethrinus lentjan & 0 & 3 & 0 & 0 & 0 & 3 & 0.36 & 0.04 & $15-22$ & $\mathrm{~J}$ \\
\hline 50. & & Lethrinus rubrioperculatus & 0 & 1 & 0 & 0 & 0 & 1 & 1.8 & 0.01 & $42-42$ & $\mathrm{~J}$ \\
\hline 51. & \multirow[t]{2}{*}{ Lutjanidae } & Lutjanus fulviflamma & 0 & 1 & 0 & 0 & 0 & 1 & 0.16 & 0.01 & $17-17$ & $\mathrm{~J}$ \\
\hline 52. & & Lutjanus lutjanus & 0 & 1 & 0 & 0 & 0 & 1 & 0.7 & 0.01 & $29-29$ & $\mathrm{~J}$ \\
\hline 53. & \multirow[t]{2}{*}{ Mullidae } & Parupeneus indicus & 0 & 1 & 0 & 0 & 0 & 1 & 0.8 & 0.01 & $37-37$ & $\mathrm{~J}$ \\
\hline 54. & & Upeneus vittatus & 0 & 1 & 3 & 0 & 0 & 4 & 57.87 & 0.06 & $67-105$ & $\mathrm{~J}, \mathrm{~A}$ \\
\hline 55. & Pomacentridae & Pomacentrus tripunctatus & 0 & 0 & 0 & 1 & 0 & 1 & 24.03 & 0.01 & $80-80$ & $\mathrm{~A}$ \\
\hline 56. & \multirow[t]{3}{*}{ Siganidae } & Siganus canaliculatus & 0 & 5 & 1 & 0 & 0 & 6 & 2.02 & 0.08 & $20-31$ & $\mathrm{~J}$ \\
\hline 57. & & Siganus guttatus & 0 & 0 & 2 & 1 & 0 & 3 & 12.59 & 0.04 & $40-68$ & $\mathrm{~J}$ \\
\hline 58. & & Siganus spinus & 0 & 14 & 6 & 0 & 0 & 20 & 3.43 & 0.28 & $15-20$ & $\mathrm{~J}$ \\
\hline 59. & \multirow[t]{2}{*}{ Sillaginidae } & Sillago aeolus & 0 & 0 & 10 & 1 & 0 & 11 & 3.16 & 0.15 & $16-30$ & $\mathrm{~J}$ \\
\hline 60. & & Sillago sihama & 0 & 0 & 1 & 0 & 2 & 3 & 11.9 & 0.04 & $38-90$ & $\mathrm{~J}$ \\
\hline 61. & \multirow[t]{2}{*}{ Sphyraenidae } & Sphyraena barracuda & 3 & 1 & 0 & 0 & 0 & 4 & 3.71 & 0.06 & $23-80$ & $\mathrm{~J}$ \\
\hline 62. & & Sphyraena flavicauda & 0 & 12 & 0 & 0 & 0 & 12 & 20.04 & 0.17 & $19-78$ & $\mathrm{~J}$ \\
\hline \multirow[t]{2}{*}{63.} & Terapontidae & Terapon jarbua & 1 & 3 & 11 & 9 & 49 & 73 & 31.77 & 1.01 & $9-60$ & $\mathrm{~J}$ \\
\hline & \multicolumn{12}{|c|}{ PLEURONECTIFORMES } \\
\hline 64. & Cynoglossidae & Cynoglossus puncticeps & 1 & 2 & 0 & 0 & 0 & 3 & 28.56 & 0.04 & $89-110$ & $\mathrm{~J}$ \\
\hline \multirow[t]{2}{*}{65.} & Paralichthyidae & Pseudorhombus arsius & 1 & 1 & 1 & 0 & 0 & 3 & 39.73 & 0.04 & $37-113$ & $\mathrm{~J}$ \\
\hline & \multicolumn{12}{|c|}{ SCORPAENIFORMES } \\
\hline 66. & Platycephalidae & Sorsogona tuberculata & 0 & 1 & 0 & 0 & 0 & 1 & 15.62 & 0.01 & $113-113$ & A \\
\hline 67. & Scorpaenidae & Parascorpaena mcadamsi & 0 & 1 & 0 & 0 & 0 & 1 & 8 & 0.01 & $57-57$ & A \\
\hline \multirow[t]{2}{*}{68.} & Tetrarogidae & Tetraroge barbata & 0 & 1 & 2 & 0 & 0 & 3 & 14.54 & 0.04 & $32-67$ & $\mathrm{~J}, \mathrm{~A}$ \\
\hline & \multicolumn{12}{|c|}{ SILURIFORMES } \\
\hline 69. & Plotosidae & Plotosus lineatus & 0 & 146 & 419 & 0 & 0 & 565 & 927.25 & 7.85 & $22-74$ & $\mathrm{~J}$ \\
\hline
\end{tabular}




\begin{tabular}{|c|c|c|c|c|c|c|c|c|c|c|c|c|}
\hline \multirow{2}{*}{ No. } & \multirow{2}{*}{ Order/ Family } & \multirow{2}{*}{ Species } & \multicolumn{5}{|c|}{ Sampling sites } & \multirow{2}{*}{$\mathrm{N}$} & \multirow{2}{*}{$\mathrm{W}(\mathrm{g})$} & \multirow{2}{*}{ CPUE } & \multirow{2}{*}{$\mathrm{SL}(\mathrm{cm})$} & \multirow{2}{*}{ LS } \\
\hline & & & St. 1 & St. 2 & St. 3 & St. 4 & St. 5 & & & & & \\
\hline & \multicolumn{12}{|c|}{ TETRAODONTIFORMES } \\
\hline 70. & Monacanthidae & Acreichthys tomentosus & 0 & 1 & 0 & 0 & 0 & 1 & 6.99 & 0.01 & $60-60$ & A \\
\hline 71. & Tetraodontidae & Arothron manilensis & 0 & 1 & 1 & 0 & 1 & 3 & 24.89 & 0.04 & $41-63$ & $\mathrm{~J}$ \\
\hline 72. & & Arothron reticularis & 0 & 0 & 0 & 1 & 1 & 2 & 164.5 & 0.03 & $35-120$ & $\mathrm{~J}$ \\
\hline 73. & & Canthigaster margaritata & 0 & 1 & 0 & 0 & 0 & 1 & 13.2 & 0.01 & $61-61$ & $\mathrm{~J}$ \\
\hline \multirow[t]{3}{*}{74.} & & Chelonodon patoca & 0 & 0 & 3 & 3 & 3 & 9 & 43.3 & 0.13 & $8-71$ & $\mathrm{~J}$ \\
\hline & & Total & 2931 & 1784 & 960 & 354 & 410 & 6439 & 4649.37 & 89.43 & & \\
\hline & & Number of species & 18 & 46 & 31 & 26 & 23 & 74 & & & & \\
\hline
\end{tabular}

